\title{
Effects of supplemental calcium salts of palm oil and chromium-propionate on insulin sensitivity and productive and reproductive traits of mid- to late- lactating Holstein $\times$ Gir dairy cows consuming excessive energy
}

\author{
T. Leiva, ${ }^{*}$ R. F. Cooke,${ }^{1}$ A. P. Brandão, $\ddagger$ R. D. Bertin, ${ }^{*}$ E. A. Colombo, ${ }^{*}$ V. F. B. Miranda, ${ }^{*}$ L. A. C. Lourenço, ${ }^{*}$ \\ S. M. B. Rodrigues, ${ }^{*}$ and J. L. M. Vasconcelos ${ }^{* 1}$ \\ *School of Veterinary Medicine and Animal Science, São Paulo State University (UNESP), Botucatu 18168-000, Brazil \\ †Department of Animal Science, Texas A\&M University, College Station 77845 \\ †Eastern Oregon Agricultural Research Center, Oregon State University, Burns 97720
}

\begin{abstract}
This experiment compared insulin sensitivity, milk production, and reproductive outcomes in dairy cows consuming excessive energy during mid to late lactation and receiving in a $2 \times 2$ factorial design (1) concentrate based on ground corn $(\mathrm{CRN} ; \mathrm{n}=20)$ or including $8 \%$ (DM basis) of Ca salts of palm oil (CSPO; $\mathrm{n}=20)$, and (2) supplemented $(\mathrm{n}=20)$ or not $(\mathrm{n}=20)$ with $2.5 \mathrm{~g} / \mathrm{d}$ of Cr-propionate. During the experiment (d 0-203), 40 multiparous, nonpregnant, lactating 3/4 Holstein $\times 1 / 4$ Gir cows (initial days in milk $=81 \pm$ 2 ; mean $\pm \mathrm{SE}$ ) were offered corn silage for ad libitum consumption, and individually received concentrate formulated to allow diets to provide $160 \%$ of their daily net energy for lactation requirements. From d -15 to 203, milk production was recorded daily, blood samples collected weekly, and cow body weight (BW) and body condition score (BCS) recorded on d 0 and 203. For dry matter intake evaluation, cows from both treatments were randomly divided in 5 groups of 8 cows each, and allocated to 8 individual feeding stations for $3 \mathrm{~d}$. Intake was evaluated 6 times/group. Glucose tolerance tests (GTT; $0.5 \mathrm{~g}$ of glucose $/ \mathrm{kg}$ of BW) were performed on d $-3,100$, and 200. Follicle aspiration for in vitro embryo production was performed via transvaginal ovum pickup on d $-1,98$, and 198. Mean DMI, net energy for lactation intake, as well as BW and BCS change were similar across treatments. On average, cows gained $40 \mathrm{~kg}$ of BW and 0.49 BCS during the experiment. Within weekly blood samples, CRN cows had lower serum concentrations of glucose, insulin, fatty acids, and insulin-to-glucose ratio compared with CSPO cows, suggesting increased insulin sensitivity in CRN
\end{abstract}

Received April 26, 2017.

Accepted August 31, 2017.

${ }^{1}$ Corresponding authors: vasconcelos@fmvz.unesp.br and reinaldocooke@tamu.edu cows. During the GTT, insulin-sensitivity traits were also greater in CRN versus CSPO cows. Supplemental $\mathrm{Cr}$-propionate resulted in lower serum insulin concentrations and insulin-to-glucose ratio within CRN cows only, indicating that $\mathrm{Cr}$-propionate improved basal insulin sensitivity in CRN but not in CSPO cows. During the GTT, however, Cr-propionate supplementation reduced hyperinsulinemia and insulin-to-glucose ratio across CSPO and CRN cows. Milk production, as well as number of viable oocytes collected and embryos produced within each aspiration, were not affected by treatments. Hence, replacing corn by Ca salts of palm oil in the concentrate did not improve insulin sensitivity in Holstein $\times$ Gir dairy cows consuming excessive energy during mid to late lactation, whereas Cr-supplementation was effective in improving basal insulin sensitivity in cows not receiving Ca salts of palm oil.

Key words: chromium, dairy cows, energy intake, fat, insulin sensitivity

\section{INTRODUCTION}

Excessive energy intake reduces insulin sensitivity and leads to insulin resistance in nonlactating and lactating Holstein $\times$ Gir dairy cows (Leiva et al., 2014, 2015). This syndrome, characterized by persistent hyperglycemia despite increased insulin secretion, has been shown to negatively affect welfare and reproductive responses of dairy cattle, particularly oocyte competence (Adamiak, 2005; Baruselli et al., 2016). Excessive energy intake is common and often inevitable among nonlactating and mid- to late-lactating cows in commercial dairies (Van Saun and Sniffen, 1996); hence, nutritional and management strategies that mitigate insulin resistance are warranted to optimize productivity and welfare of dairy cattle.

Chromium is a critical component of the glucose tolerance factor and facilitates the action of insulin on body cells (Mertz, 1992; Vincent, 2001). Accordingly, 
supplementing Cr-propionate to nonlactating and midto late-lactating Holstein $\times$ Gir dairy cows prevented the decrease in insulin sensitivity caused by excessive energy intake (Leiva et al., 2014, 2015). Insulin resistance can also be caused by chronic hyperinsulinemia, which downregulates insulin receptors and decreases cellular sensitivity to insulin (Moller and Flier, 1991). Thus, reducing dietary content of insulinogenic ingredients, such as starch, may also mitigate the incidence of this syndrome in cattle. Garnsworthy et al. (2008) reported that reducing starch intake by substituting wheat for $\mathrm{Ca}$ salts of palm oil reduced mean plasma insulin concentrations in lactating dairy cows, although the effects of this dietary strategy on insulin-sensitivity traits still needs investigation.

Based on this information, we hypothesized that replacing corn by Ca salts of palm oil in the dietary concentrate mitigates the decline in insulin sensitivity in lactating Holstein $\times$ Gir dairy cows consuming excessive energy, whereas Cr-propionate supplementation is an alternative to further alleviate this outcome. Therefore, the current experiment compared insulin-sensitivity traits, milk production, and reproductive outcomes in Holstein $\times$ Gir dairy cows consuming excessive energy during mid and late lactation receiving a corn-based concentrate including or not $\mathrm{Ca}$ salts of palm oil and supplemented or not with Cr-propionate.

\section{MATERIALS AND METHODS}

This experiment was conducted at the São Paulo State University-Lageado Experimental Station, located in Botucatu, São Paulo, Brazil. The animals used were cared for in accordance with acceptable practices and experimental protocols reviewed and approved by the São Paulo State University-Animal Ethics Committee (\#17/2015).

\section{Animals and Diets}

Forty lactating, multiparous, nonpregnant 3/4 Holstein $\times 1 / 4$ Gir cows (initial mean $\pm \mathrm{SE}$; parity $=2.3$ $\pm 0.12, \mathrm{BW}=590 \pm 9.4 \mathrm{~kg}, \mathrm{BCS}=3.18 \pm 0.06$, milk yield $=26.9 \pm 0.95 \mathrm{~kg}$, and $\mathrm{DIM}=81 \pm 2$ ) were assigned to this experiment (d 0-203). On d 0, cows were ranked by DIM, milk yield, BW, and BCS (Wildman et al., 1982), and assigned to $2 \times 2$ factorial arrangement design with treatments of (1) concentrate based only on ground corn $(\mathbf{C R N} ; \mathrm{n}=20)$ or including $8 \%$ (DM basis) of Ca salts of palm oil (CSPO; EnerFAT Kemin Agrifoods South America, Indaiatuba, São Paulo, Brazil; $\mathrm{n}=20)$, and (2) supplemented $(\mathrm{n}=20)$ or not $(\mathrm{n}=20)$ with $2.5 \mathrm{~g} / \mathrm{d}$ of Cr-propionate $(10 \mathrm{mg}$ of $\mathrm{Cr} /$ cow daily; KemTrace 0.4\% Cr; Kemin Agrifoods South
Table 1. Composition and nutritional profile of concentrate based on ground corn $(\mathrm{CRN} ; \mathrm{n}=20)$ or with the inclusion of Ca salts of palm fatty oil (CSPO; $\mathrm{n}=20$ )

\begin{tabular}{lcc}
\hline Item & CRN & CSPO \\
\hline Composition, \% (as-fed basis) & & \\
Ground corn & 69.0 & 59.5 \\
Soybean meal & 28.0 & 29.5 \\
Ca salts of palm fatty acids ${ }^{1}$ & - & 8.0 \\
Mineral mix & 3.0 & 3.0 \\
Nutritional profile (DM basis) & & \\
NDF, \% & 11.8 & 11.1 \\
Starch, \% & 50.2 & 42.8 \\
Crude fat, \% & 3.3 & 10.3 \\
NE & 2.13 & 2.36 \\
NE, Mcal/kg & 1.96 & 2.24 \\
CP, \% & 20.4 & 20.3 \\
\hline
\end{tabular}

${ }^{1}$ EnerFAT (Kemin Agrifoods South America, Indaiatuba, São Paulo, Brazil).

${ }^{2}$ Containing $22 \% \mathrm{Ca}, 7.5 \% \mathrm{P}, 6.5 \% \mathrm{Na}, 1.0 \% \mathrm{~K}, 3.6 \% \mathrm{Mg}, 2.0 \% \mathrm{~S}$, $0.003 \%$ Co, $0.115 \%$ Cu, $0.004 \%$ I, $0.220 \%$ Mn, $0.003 \%$ Se, $0.400 \%$ $\mathrm{Zn}, 400,000 \mathrm{IU} / \mathrm{kg}$ of vitamin $\mathrm{A}, 100,000 \mathrm{IU} / \mathrm{kg}$ of vitamin $\mathrm{D}_{3}$, and $0.150 \%$ vitamin E (Milk MAC; M. Cassab Tecnologia Animal, São Paulo, Brazil).

America). All treatment combinations had equivalent initial average DIM, milk yield, BW, and BCS.

From $d-15$ to 203 , cows were maintained in a single drylot pen with ad libitum access to corn silage, water, and a commercial mineral mix without the inclusion of $\mathrm{Cr}$ (described in Table 1). Corn silage was provided in feed bunks that allowed $1.5 \mathrm{~m}$ of linear bunk space/ cow and offered at daily rates to result in $\geq 15 \%$ (DM basis) of nonconsumed silage. Cows were milked twice daily in a side-by-side milking system (0600 and 1700 $\mathrm{h}$ ), and individually received their concentrate through self-locking head gates immediately after each milking.

From d -15 to -1 (adaptation period), cows received a concentrate containing (as-fed basis) $40 \%$ of soybean meal, $57 \%$ of ground corn, and $3.0 \%$ of a commercial mineral mix (described in Table 1). From d 0 to 203, cows received concentrate treatments described in Table 1. Concentrate intake was formulated to each individual cow so the diet (concentrate + corn silage) provided 100 (d -15 to -1 ) or $160 \%$ (d 0-203) of their daily $\mathrm{NE}_{\mathrm{L}}$ requirements, as previously described and accomplished by Leiva et al. (2015). All dietary treatments were formulated to similarly meet CP, mineral, and vitamin requirements (NRC, 2001). Concentrate intake was adjusted weekly (d -15 to 203) using the Spartan Dairy Ration Evaluator/Balancer (version 3.0; Michigan State University, East Lansing, MI) according to DIM, milk yield, BW, BCS, treatment, and corn silage intake estimated by the software.

Chromium-propionate was offered in the amount recommended by the manufacturer $(2.5 \mathrm{~g} / \mathrm{cow}$ daily of KemTrace; Kemin Agrifoods South America), mixed with $97.5 \mathrm{~g}$ of finely ground corn, and top-dressed daily 
into the morning concentrate feeding of each supplemented cow. Finely ground corn $(97.5 \mathrm{~g} / \mathrm{cow})$ was also top-dressed into the morning concentrate feeding of cows not assigned to Cr-propionate supplementation, but without the addition of the Cr-propionate. Based on daily visual observations, all cows consumed the top-dress within 5 min after feeding. The Ca salts of palm oil was added to the CSPO concentrate to result in less than $6 \%$ of total dietary crude fat (NRC, 2001) according to the expected corn silage and concentrate DMI based on Leiva et al. (2015, 2017b).

\section{Sampling}

Intake Variables. Samples of the offered feed ingredients were collected every $15 \mathrm{~d}$ during the experimental period, pooled into 1 sample, and analyzed for nutrient content (Table 1) via wet chemistry procedures by a bromatology laboratory (3rlab, Belo Horizonte, Brazil). Calculations of $\mathrm{NE}_{\mathrm{L}}$ and $\mathrm{NE}_{\mathrm{M}}$ used the equations proposed by the NRC (2001). Nutritive value of corn silage was $37.8 \% \mathrm{DM}, 1.44 \mathrm{Mcal} / \mathrm{kg}$ of $\mathrm{NE}_{\mathrm{L}}, 1.57 \mathrm{Mcal} / \mathrm{kg}$ of $\mathrm{NE}_{\mathrm{M}}, 20.1 \%$ starch, $3.1 \%$ crude fat, and $7.1 \% \mathrm{CP}$ (DM basis). Nutritive values of experimental concentrates are described in Table 1. Nutritive value of concentrate offered from d -15 to -1 was $90.1 \% \mathrm{DM}, 1.96 \mathrm{Mcal} / \mathrm{kg}$ of $\mathrm{NE}_{\mathrm{L}}, 1.96 \mathrm{Mcal} / \mathrm{kg}$ of $\mathrm{NE}_{\mathrm{M}}, 49.1 \%$ starch, $3.2 \%$ crude fat, and $23.1 \% \mathrm{CP}$ (DM basis).

To determine treatment effects on voluntary DMI, cows from both treatments were randomly divided in 5 feeding groups of 8 cows each (2 cows/treatment combination in each group). Cows from each feeding group were allocated to 8 individual feeding stations $\left(15 \mathrm{~m}^{2}\right.$; $2.0 \mathrm{~m}$ of linear bunk space) with soft rubber flooring for $3 \mathrm{~d}$, as in Leiva et al. (2017a). During this period, cows from the selected feeding group continued to have ad libitum access to water and corn silage and received treatments after milking as previously described. Corn silage DMI was evaluated daily from each feeding station by collecting and weighing refusals daily. Samples of the offered and nonconsumed corn silage were collected daily from each feeding station and dried for $96 \mathrm{~h}$ at $50^{\circ} \mathrm{C}$ in forced-air ovens for DM calculation. At the end of the 3-d period, cows returned to the dry lot pen and another feeding group was assigned to the individual feeding stations, in a manner that corn silage DMI was evaluated 6 times/feeding group during the experimental period.

Cow Productive Variables. Cow BW and BCS were recorded weekly before $(\mathrm{d}-15$ to -1$)$ and during the experimental period ( $\mathrm{d} 0-203)$. Cow milk production was recorded daily from $\mathrm{d}-15$ to 203 . These variables were used to adjust concentrate intake of each cow on a weekly basis. Further, BCS was evaluated (Wildman et al., 1982) by the same 2 evaluators throughout the experiment, and evaluators were blinded to which treatment the assessed cow was assigned to. However, cow BCS and BW on d 0 and 203 were used to determine treatment effects on these variables. Milk samples were collected weekly (d -15 to 203) from each cow during both milkings of the day, combined into 1 daily sample (50 mL from each milking). Milk samples were analyzed for SCC via flow cytometry (AOAC, 1990) with a Somacount 300 instrument (Bentley Instruments Inc., Chaska, MN), and concentrations of fat, protein, and TS via infrared spectrometry (method 972.16; AOAC International, 1999), by a commercial laboratory (Clínica do Leite; Universidade de São Paulo, Piracicaba, Brazil). Daily milk yield was adjusted to FCM or TScorrected milk based on milk concentrations of fat and TS, respectively, of the concurrent week. Starch, fat, and $\mathrm{NE}_{\mathrm{L}}$ intake within each treatment were estimated according to the NRC (2001) model, using dietary nutrient profile, average milk yield, BW, BCS, and DMI values observed during the experimental period.

Blood samples were collected weekly (d 0-203), before the morning concentrate feeding during the experiment for determination of serum glucose, insulin, and fatty acid concentrations. Serum insulin and glucose concentrations within each sampling time were used to calculate insulin to glucose ratio (I:G; Bernhard et al., 2012) and homeostasis model of insulin resistance (HOMA-IR; Mann et al., 2016). Glucose tolerance tests (GTT) were performed on d $-3,100$, and 200 by intravenously infusing cows with $0.5 \mathrm{~g}$ of glucose $/ \mathrm{kg}$ of BW. More specifically, cows were weighed the day before each GTT and had access to water but were not offered corn silage, Cr-propionate, or concentrate $12 \mathrm{~h}$ before and during the GTT. Cows were fitted with indwelling jugular catheters according to the procedures described by Curley et al. (2008) immediately before infusion and received a $50 \%$ saline:dextrose solution via gravity intravenous infusion (Glicocalbos 50\%; Calbos Saúde Animal, Curitiba, Brazil) according to their BW (1 $\mathrm{g}$ of saline:dextrose solution $/ \mathrm{kg}$ of $\mathrm{BW}$ ). Across all GTT, total glucose infusion time was $9.9 \pm 0.5 \mathrm{~min}$. Catheters were removed after infusion was complete. Blood samples were collected at $-15,0,10,20,30,45$, 60, 90, and 120 min relative to infusion and analyzed for serum concentrations of glucose and insulin. During each GTT, area under the curve (AUC) for glucose and insulin were calculated with the trapezoidal method (Shiang, 2004), whereas I:G and HOMA-IR were also determined within each sampling time (Bernhard et al., 2012). Glucose clearance rate and half-life were calculated with the equations described by Bernhard et al. (2012), using incremental serum glucose concentrations between 30 and 120 min postinfusion during the GTT. 


\section{Laboratorial Analysis}

During the weekly or GTT blood collections, samples were obtained from coccygeal vessels into commercial blood collection tubes containing no additives or anticoagulants (Vacutainer, $10 \mathrm{~mL}$; Becton Dickinson, Franklin Lakes, NJ), placed immediately on ice, centrifuged at $3,000 \times g$ at $4^{\circ} \mathrm{C}$ for 30 min for serum collection, and stored at $-20^{\circ} \mathrm{C}$ on the same day of collection. Glucose, insulin, and fatty acid concentrations were analyzed as in Leiva et al. (2015). The intra- and interassay coefficients of variation were, respectively, 3.6 and $6.2 \%$ for glucose, 2.1 and $3.0 \%$ for insulin, and 6.7 and $9.3 \%$ for fatty acids. Assay sensitivity was $0.0005 \mathrm{mmol} / \mathrm{L}$ for glucose, $0.01 \mathrm{mmol} / \mathrm{L}$ for fatty acids, and $0.1 \mu \mathrm{IU} / \mathrm{mL}$ for insulin.

\section{Reproductive Management}

Follicle aspiration was performed on $\mathrm{d}-1,98$, and 198 to evaluate treatment effects on production of viable oocytes, as well as subsequent in vitro embryo production. Cows were at random stages of the estrous cycle when assigned to follicle aspiration, which was performed via transvaginal ovum pick-up according to the procedures described by Bilby et al. (2006). Oocytes were collected, processed, and maturated for in vitro fertilization as described by Leiva et al. (2015), and fertilized with semen from the same sire according to the procedures described by Bilby et al. (2006). Presumptive zygotes were incubated at $38.5^{\circ} \mathrm{C}$ in $5 \% \mathrm{O}_{2}$, $5 \% \mathrm{CO}_{2}$, in $100 \%$ humidified air for $7 \mathrm{~d}$ (Bilby et al., 2006). After incubation, number of cleaved and viable embryos was recorded with a dissecting microscope. Variables that were used for the present experiment were number of oocytes collected that were viable to in vitro fertilization (grades I, II, and III; Bilby et al., 2006), number of embryos produced, and ratio of embryos produced to viable oocytes collected within each sampling day.

\section{Statistical Analysis}

Cow was considered the experimental unit given that concentrate energy source (CRN or CSPO) and Cr supplementation were individually applied to cows. All data were analyzed using SAS (SAS Institute Inc., Cary, NC; version 9.3) with Satterthwaite approximation to determine the denominator degrees of freedom for the tests of fixed effects (Overholt et al., 2016). The MIXED procedure was used for analyses of quantitative data. The GLIMMIX procedure was used for analysis of number of viable oocytes collected and embryos produced per collection using Poisson distribution, as well as proportion of embryo produced per oocyte collected using Binomial distribution. Cow (concentrate energy source $\times$ Cr-propionate supplementation) was included as random variable into all analyses, but DMI used cow (concentrate energy source $\times$ Cr-propionate supplementation $\times$ feeding group).

The model statement used for analysis of BW and BCS change, as well as initial and final BCS and BW during the experiment, contained the effect of concentrate energy source, Cr-propionate supplementation, and the resultant interaction. The model statement used for analysis of weekly BW, BCS, milk yield, and serum variables contained the effects of concentrate energy source, Cr-propionate supplementation, time (day or week), and the resultant interactions. Average milk production and milk component concentrations from $\mathrm{d}-15$ to -1 , as well as results from serum samples collected on d 0 , were included as covariate within each respective analysis. The model statement used for analysis of DMI and nutrient intake contained the effects of concentrate energy source, $\mathrm{Cr}$-propionate supplementation, day, feeding group, and all resultant interactions. The model statement used for serum glucose, serum insulin, I:G, and HOMA-IR obtained during the GTT contained the effects of concentrate energy source, Cr-propionate supplementation, day of GTT, minute of sampling, all resultant interactions, and averaged values obtained from the GTT on d -3 as independent covariate. The model statement used for follicle aspiration and in vitro fertilization outcomes, as well as glucose and insulin AUC, glucose clearance rate, and glucose half-life during the GTT contained the effects of concentrate energy source, Cr-propionate supplementation, day of follicle collection or GTT, all resultant interactions, and values obtained from collection on $\mathrm{d}-1$ (reproductive variables) or -3 (GTT) as independent covariate. The specified term for the repeated statement within GTT results was week for the weekly collections, day for reproductive variables, day (feeding group) for $\mathrm{NE}_{\mathrm{L}}$ intake and $\mathrm{DMI}$, and hour for the GTT. Cow (concentrate energy source $\times$ Crpropionate supplementation) was included as subject for all repeated statements, but $\mathrm{NE}_{\mathrm{L}}$ intake and $\mathrm{DMI}$ included cow (concentrate energy source $\times$ Cr-propionate supplementation $\times$ feeding group) as subject. The covariance structure used for all repeated statements was autoregressive, which provided the best fit for these analyses according to the Akaike information criterion.

Results are reported as least squares means, or covariately adjusted means for GTT, milk yield, and weekly serum variables; reproductive results are reported as actual means. All results were separated using Bonferroni-adjusted PDIFF to prevent type I errors. Significance was set at $P \leq 0.05$, and tendencies were 
determined if $P>0.05$ and $\leq 0.10$. Results are reported according to main treatment effects (concentrate energy source and $\mathrm{Cr}$ supplementation) if no interactions were significant, or according to the highest-order significant $(P \leq 0.05)$ interaction contained 1 of both main treatment effects.

\section{RESULTS}

\section{Intake, BW, and BCS Variables}

Mean DMI during the experiment, as kilograms per day or percentage of $\mathrm{BW}$, were similar $(P \geq 0.25)$ within concentrate energy source or $\mathrm{Cr}$ supplementation effects (Table 2). No differences among mean $\mathrm{NE}_{\mathrm{L}}$ intake, percentage of $\mathrm{NE}_{\mathrm{L}}$ intake according to requirements (NRC, 2001), and mean starch intake were detected $(P \geq 0.53)$ within concentrate energy source or $\mathrm{Cr}$ supplementation effects (Table 2). However, mean dietary starch content was greater $(P<0.01)$ in CRN versus CSPO cows, and similar $(P=0.59)$ between $\mathrm{Cr}$ supplementation treatments (Table 2). Mean crude fat intake and dietary crude fat content were greater $(P$ $<0.01)$ in CSPO versus CRN cows, and similar $(P=$ 0.38 ) between $\mathrm{Cr}$ supplementation treatments (Table $2)$.

No concentrate energy source or Cr supplementation effects were detected $(P \geq 0.22)$ for final $\mathrm{BW}$ and $\mathrm{BW}$ change, as well as final BCS and BCS change (Table
3 ). Moreover, all cows gained (day effect, $P<0.01$ ) BW (560 vs. $600 \mathrm{~kg}$ on d 0 and 203, respectively; SEM $=11$ ) and BCS (3.18 vs. 3.67 of BCS on d 0 and 203, respectively; $\mathrm{SEM}=0.07$ ) during the experiment.

\section{Serum Variables Evaluated Weekly}

A concentrate energy source $x$ day interaction was detected $(P=0.01)$ for serum glucose; CSPO cows often had greater serum glucose concentrations compared with CRN cows (Figure 1). Accordingly, mean serum glucose concentrations during the experimental period were greater in CSPO versus CRN cows (Table 4). A tendency for $\mathrm{Cr}$ supplementation effect was detected $(P=0.09)$ for serum glucose, as Cr-supplemented cows had lower mean serum glucose concentrations compared with nonsupplemented cohorts during the experimental period (Table 4).

Concentrate energy source $\times$ Cr supplementation $\times$ day interactions were detected $(P \leq 0.04)$ for serum insulin, I:G, and HOMA-IR. Cows receiving CRN + Cr-propionate often had lower $(P \leq 0.05)$ serum insulin concentrations (Figure 2), I:G (Figure 3), and HOMAIR (data not shown) compared with all other treatment combinations. Accordingly, mean serum insulin concentrations, I:G, and HOMA-IR were lower $(P \leq$ $0.05)$ in Cr-supplemented versus non-supplemented CRN cows, but similar $(P \geq 0.93)$ within CSPO cows (Table 5; concentrate energy source $\times$ Cr supplemen-

Table 2. Feed and nutrient intake of $3 / 4$ Holstein $\times 1 / 4$ Gir dairy cows consuming excessive energy during mid to late lactation and receiving in a $2 \times 2$ factorial arrangement design (1) concentrate based only on ground corn (CRN; $\mathrm{n}=20$ ) or including $8 \%$ (DM basis) of Ca salts of palm oil (CSPO; EnerFAT Kemin Agrifoods South America, Indaiatuba, São Paulo, Brazil; n = 20), and (2) supplemented ( $\mathrm{n}=20)$ or not (n $=20)$ with $2.5 \mathrm{~g} / \mathrm{d}$ of Cr-propionate $(10 \mathrm{mg} \text { of } \mathrm{Cr} / \text { cow daily; KemTrace } 0.4 \% \mathrm{Cr} \text {; Kemin Agrifoods South America })^{1,2}$

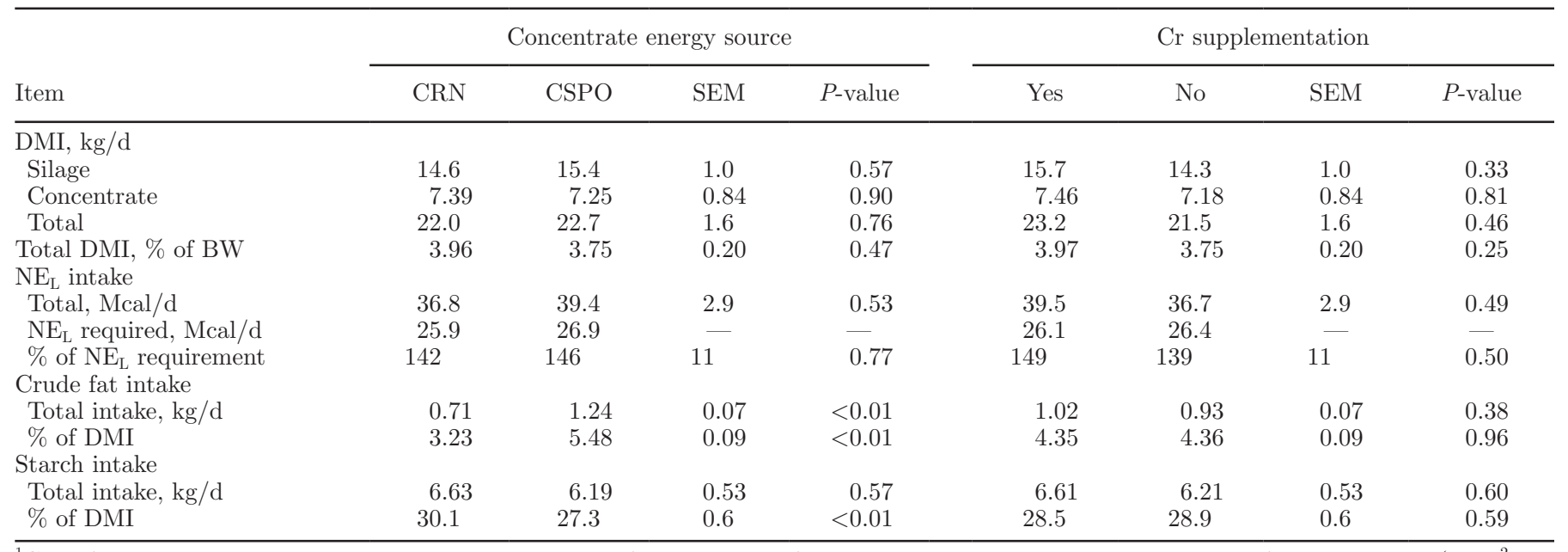

${ }^{1}$ Cows from both treatments were randomly divided in 5 feeding group of 8 cows each, and allocated to 8 individual feeding stations $\left(15 \mathrm{~m}^{2} ; 2.0\right.$ $\mathrm{m}$ of linear bunk space) for $3 \mathrm{~d}$ as in Leiva et al. (2017a). Corn silage and concentrate DMI were evaluated daily from each cow by collecting and weighing refusals daily. At the end of the 3 -d period, cows returned to the dry lot pen and another feeding group was assigned to the individual feeding stations, in a manner that DMI was evaluated 6 times/feeding group during the experimental period.

${ }^{2}$ Starch, crude fat, and $\mathrm{NE}_{\mathrm{L}}$ intake and requirements within each treatment were estimated according to the NRC (2001) model, using dietary nutrient profile, average milk yield, BW, BCS, and DMI values observed during the experimental period. 


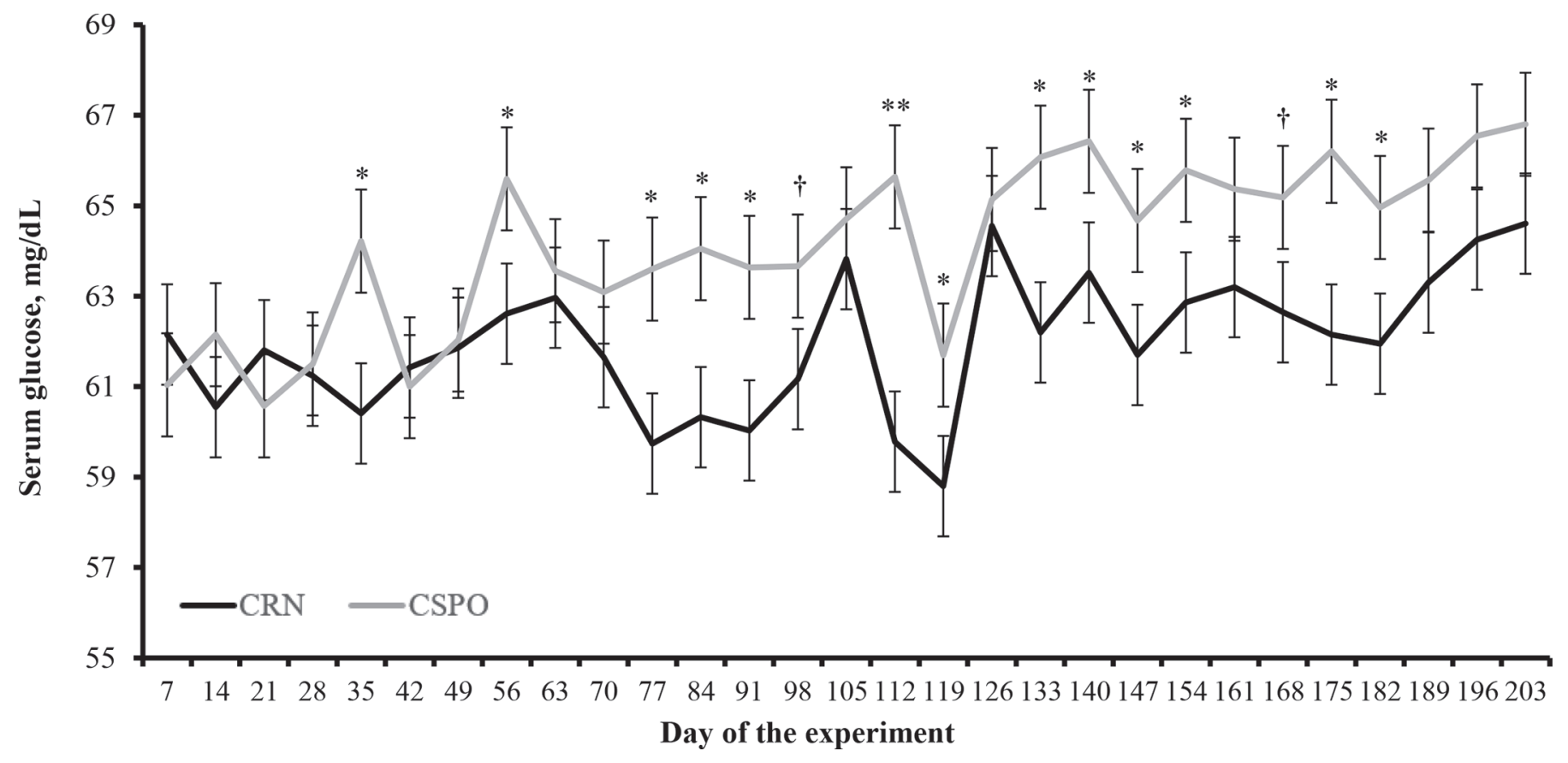

Figure 1. Serum glucose concentrations of $3 / 4$ Holstein $\times 1 / 4$ Gir dairy cows consuming excessive energy during mid to late lactation and receiving in a $2 \times 2$ factorial arrangement design (1) concentrate based only on ground corn (CRN; $\mathrm{n}=20$ ) or including $8 \%$ (DM basis) of Ca salts of palm oil (EnerFAT Kemin Agrifoods South America, Indaiatuba, São Paulo, Brazil; CSPO; n = 20), and (2) supplemented (n = 20) or not $(\mathrm{n}=20)$ with $2.5 \mathrm{~g} / \mathrm{d}$ of Cr-propionate $(10 \mathrm{mg}$ of $\mathrm{Cr} / \mathrm{cow}$ daily; KemTrace $0.4 \% \mathrm{Cr}$; Kemin Agrifoods South America). Values obtained on d 0 were included as covariate; therefore, values reported are covariately adjusted means. A concentrate type $\times$ day interaction was detected $(P$ $=0.01)$. Within days, ${ }^{* *} P \leq 0.01,{ }^{*} P \leq 0.05$, and $\dagger P \leq 0.10$. Error bars represent SEM.

tation interaction, $P \leq 0.10)$. Moreover, mean serum insulin concentrations, I:G, and HOMA-IR during the experimental period were $(P \leq 0.02)$ greater in CSPO versus CRN cows (Table 4).

A concentrate energy source $\times \mathrm{Cr}$ supplementation interaction was detected $(P<0.01)$ for serum fatty acids (Table 5). During the experimental period, mean serum fatty acid concentrations were lower $(P<0.01)$ in Cr-supplemented versus nonsupplemented CSPO cows, but similar $(P=0.91)$ within $\mathrm{CRN}$ cows (Table
5). In addition, CSPO cows has greater $(P<0.01)$ mean serum fatty acid concentrations compared CRN cows during the experiment (Table 4).

\section{Serum Variables Evaluated During the GTT}

A concentrate energy source $\times$ min interaction was detected $(P<0.01)$ for serum glucose, given that peak serum glucose concentration was greater $(P<0.01)$ in CRN versus CSPO cows (Figure 4 ). However, glucose

Table 3. Body weight and BCS of $3 / 4$ Holstein $\times 1 / 4$ Gir dairy cows consuming excessive energy during mid to late lactation, and receiving in a $2 \times 2$ factorial arrangement design (1) concentrate based only on ground corn (CRN; $n=20$ ) or including $8 \%$ (DM basis) of Ca salts of palm oil (CSPO; EnerFAT Kemin Agrifoods South America, Indaiatuba, São Paulo, Brazil; n = 20), and (2) supplemented ( $\mathrm{n}=20)$ or not $(\mathrm{n}=20)$ with $2.5 \mathrm{~g} / \mathrm{d}$ of Cr-propionate $(10 \mathrm{mg} \text { of } \mathrm{Cr} / \text { cow daily; KemTrace } 0.4 \% \mathrm{Cr} \text {; Kemin Agrifoods South America })^{1}$

\begin{tabular}{|c|c|c|c|c|c|c|c|c|}
\hline \multirow[b]{2}{*}{ Item } & \multicolumn{4}{|c|}{ Concentrate energy source } & \multicolumn{4}{|c|}{ Cr supplementation } \\
\hline & $\mathrm{CRN}$ & CSPO & SEM & $P$-value & Yes & No & SEM & $P$-value \\
\hline \multicolumn{9}{|l|}{$\mathrm{BW}, \mathrm{kg}$} \\
\hline Initial BW (d 0) & 552 & 568 & 13 & 0.39 & 558 & 562 & 13 & 0.80 \\
\hline Final BW (d 210) & 593 & 605 & 18 & 0.64 & 592 & 607 & 19 & 0.57 \\
\hline BW change & 33 & 48 & 12 & 0.39 & 33 & 48 & 12 & 0.36 \\
\hline \multicolumn{9}{|l|}{ BCS } \\
\hline BCS change & 0.44 & 0.50 & 0.08 & 0.58 & 0.43 & 0.52 & 0.08 & 0.43 \\
\hline
\end{tabular}

${ }^{1}$ According to Wildman et al. (1982). 
AUC, half-life, and clearance rate were similar $(P=$ 0.40) between CSPO and CRN cows (Table 4). No Cr supplementation effects were detected $(P \geq 0.39)$ for serum glucose concentrations (172 vs. $177 \mathrm{mg} / \mathrm{dL}$ for Cr-supplemented and nonsupplemented cows, respectively; SEM = 4.5), as well as glucose AUC, half-life, and clearance rate during the GTT (Table 4)

Concentrate energy source $\times$ min interactions were detected $(P \leq 0.02)$ for serum insulin, I:G, and HOMAIR during the GTT. Serum insulin concentrations were greater $(P \leq 0.05)$ in CSPO versus CRN cows beginning at $20 \mathrm{~min}$ (Figure 5a), whereas I:G (Figure 6a) and HOMA-IR (data not shown) were often greater $(P$ $\leq 0.05)$ in CSPO versus CRN cows before and after glucose infusion. Accordingly, serum insulin AUC during the GTT were lower $(P=0.03)$ in $\mathrm{CRN}$ versus CSPO cows (Table 4). A Cr supplementation $\times$ minute interaction was detected $(P=0.03)$ for serum insulin during the GTT, which was greater $(P=0.05)$ at 30 min and tended to be greater $(P=0.09)$ at $45 \mathrm{~min}$ relative to glucose infusion in nonsupplemented versus supplemented cows (Figure 5b). No differences were detected $(P=0.57)$ for serum insulin AUC between cows supplemented or not with Cr-propionate (Table 4). Although a $\mathrm{Cr}$ supplementation $\times$ minute interaction was also detected $(P<0.01)$ for I:G during the GTT, only numerical differences were detected $(P \geq$ $0.16)$ between nonsupplemented versus supplemented cows (Figure 6b).

\section{Milk Production}

No concentrate energy source effects were detected $(P \geq 0.24$; Table 6$)$ for milk yield, milk fat, milk protein, SCC, milk TS, as well as 3.5\% FCM yield and $12 \%$ SCM. Cows supplemented with Cr-propionate had $(P$ $=0.05$ ) lower milk fat compared with nonsupplemented cows, whereas no further $\mathrm{Cr}$ supplementation effects were detected $(P \geq 0.21)$ for milk production variables (Table 6).

\section{Reproductive Variables}

No concentrate energy source or $\mathrm{Cr}$ supplementation effects were detected $(P \geq 0.35)$ for number of viable oocytes collected (6.1 and. 7.7 for $\mathrm{CRN}$ and CSPO cows, respectively, $\mathrm{SEM}=1.4 ; 7.4$ and 6.4 for Cr-supplemented and nonsupplemented cows, respectively, SEM = 1.4), embryos produced per collection (0.83 and 0.95 for CRN and CSPO cows, respectively, $\mathrm{SEM}=0.40 ; 0.62$ and 1.16 for Cr-supplemented and nonsupplemented cows, respectively, SEM $=0.40$ ), or proportion of embryo produced per oocyte collected (9.5 and 7.1 for CRN and CSPO cows, respectively, 


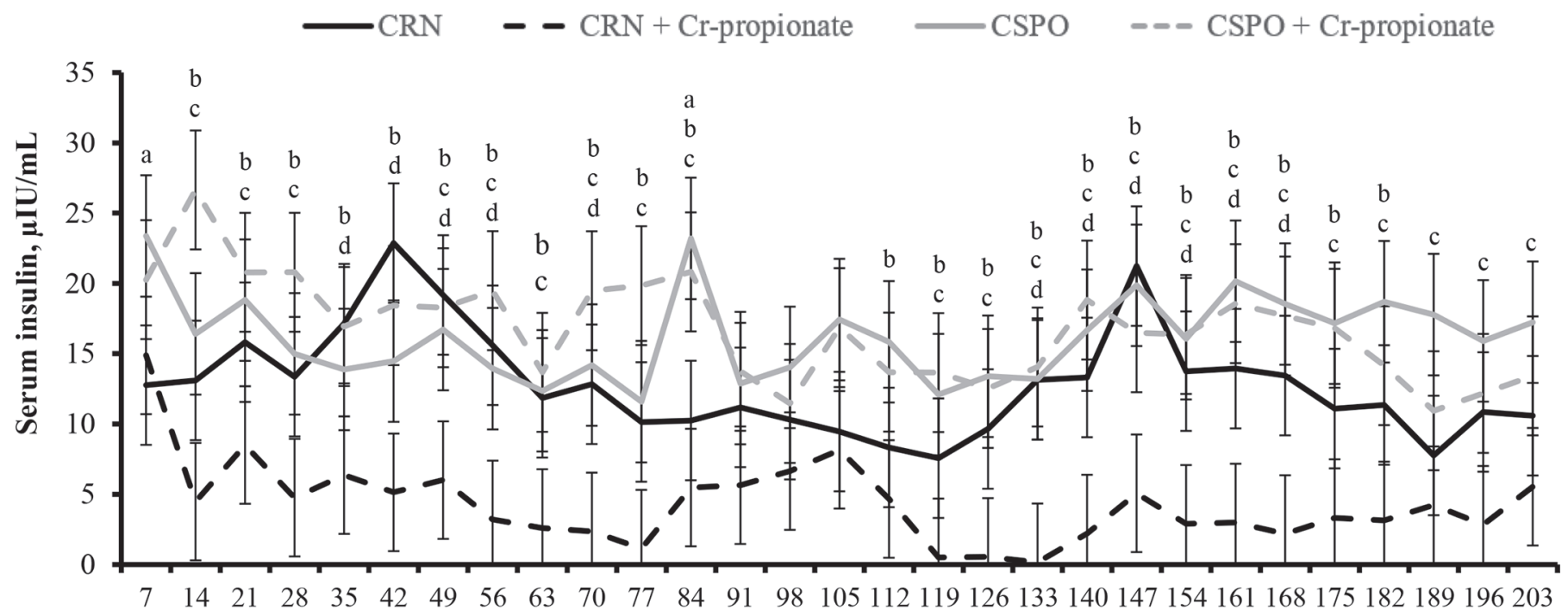

Day of the experiment

Figure 2. Serum insulin concentrations of $3 / 4$ Holstein $\times 1 / 4$ Gir dairy cows consuming excessive energy during mid to late lactation and receiving in a $2 \times 2$ factorial arrangement design (1) concentrate based only on ground corn (CRN; $\mathrm{n}=20)$ or including $8 \%$ (DM basis) of Ca salts of palm oil (EnerFAT Kemin Agrifoods South America, Indaiatuba, São Paulo, Brazil; CSPO; n = 20), and (2) supplemented ( $\mathrm{n}=20$ ) or not $(\mathrm{n}=20)$ with $2.5 \mathrm{~g} / \mathrm{d}$ of Cr-propionate $(10 \mathrm{mg}$ of $\mathrm{Cr} /$ cow daily; KemTrace $0.4 \% \mathrm{Cr}$; Kemin Agrifoods South America). Values obtained on $\mathrm{d} 0$ were included as covariate; therefore, values reported are covariately adjusted means. A concentrate type $\times$ Cr supplementation $\times$ day interaction was detected $(P=0.02)$. Within days $(P \leq 0.05), \mathrm{a}=\mathrm{CRN}$ vs. CSPO; $\mathrm{b}=\mathrm{CRN}+\mathrm{Cr}-$ propionate vs. CSPO $+\mathrm{Cr}-$ propionate; $\mathrm{c}=$ CRN + Cr-propionate vs. CSPO; $\mathrm{d}=\mathrm{CRN}$ vs. CRN + Cr-propionate. Error bars represent SEM.

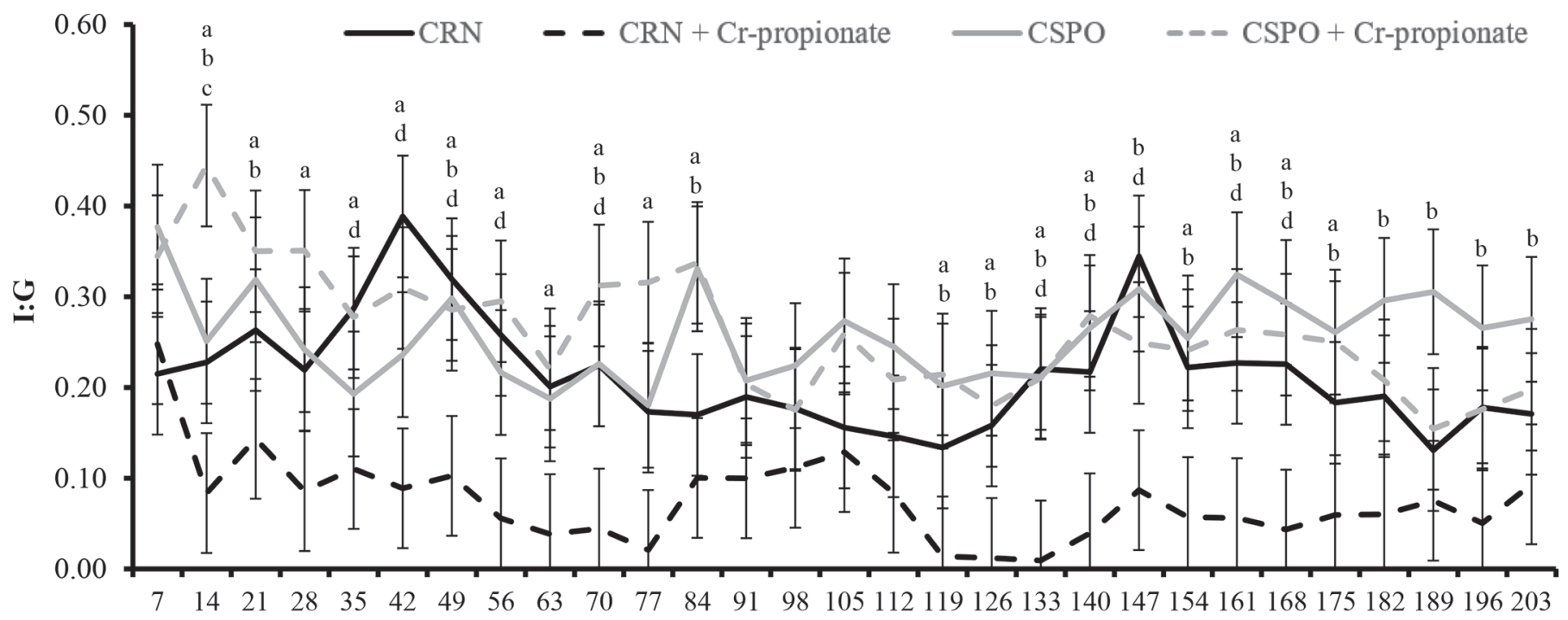

Day of the experiment

Figure 3. Serum insulin:glucose ratio (I:G) of $3 / 4$ Holstein $\times 1 / 4$ Gir dairy cows consuming excessive energy during mid to late lactation and receiving in a $2 \times 2$ factorial arrangement design (1) concentrate based only on ground corn (CRN; $\mathrm{n}=20)$ or including $8 \%$ (DM basis) of Ca salts of palm oil (EnerFAT Kemin Agrifoods South America, Indaiatuba, São Paulo, Brazil; CSPO; n = 20), and (2) supplemented ( $\mathrm{n}=20$ ) or not $(\mathrm{n}=20)$ with $2.5 \mathrm{~g} / \mathrm{d}$ of Cr-propionate $(10 \mathrm{mg}$ of $\mathrm{Cr} / \mathrm{cow}$ daily; KemTrace $0.4 \% \mathrm{Cr}$; Kemin Agrifoods South America). Values obtained on $\mathrm{d} 0$ were included as covariate; therefore, values reported are covariately adjusted means. A concentrate type $\times$ Cr supplementation $\times$ day interaction was detected $(P=0.02)$. Within days $(P \leq 0.05)$, a $=\mathrm{CRN}+$ Cr-propionate vs. CSPO $+\mathrm{Cr}$-propionate; $\mathrm{b}=\mathrm{CRN}+\mathrm{Cr}-$ propionate vs. CSPO; $\mathrm{c}=\mathrm{CSPO}$ vs. CSPO + Cr-propionate; $\mathrm{d}=\mathrm{CRN}$ vs. CRN + Cr-propionate. Error bars represent SEM. 
Table 5. Serum variables of $3 / 4$ Holstein $\times 1 / 4$ Gir dairy cows consuming excessive energy during mid to late lactation and receiving in a 2 $\times 2$ factorial arrangement design (1) concentrate based only on ground corn (CRN; $n=20$ ) or including $8 \%$ (DM basis) of Ca salts of palm oil (CSPO; EnerFAT Kemin Agrifoods South America, Indaiatuba, São Paulo, Brazil; $\mathrm{n}=20)$, and (2) supplemented $(\mathrm{n}=20)$ or not $(\mathrm{n}=20)$ with $2.5 \mathrm{~g} / \mathrm{d}$ of Cr-propionate $(10 \mathrm{mg} \text { of } \mathrm{Cr} / \mathrm{cow} \text { daily; KemTrace } 0.4 \% \mathrm{Cr} \text {; Kemin Agrifoods South America })^{1,2}$

\begin{tabular}{|c|c|c|c|c|c|c|}
\hline \multirow[b]{2}{*}{ Item } & \multicolumn{2}{|c|}{$\mathrm{CRN}$} & \multicolumn{2}{|c|}{ CSPO } & \multirow[b]{2}{*}{ SEM } & \multirow[b]{2}{*}{$P$-value } \\
\hline & $\mathrm{Cr}$ & No $\mathrm{Cr}$ & $\mathrm{Cr}$ & No $\mathrm{Cr}$ & & \\
\hline Homeostasis model of insulin resistance ${ }^{3}$ & $0.091^{\mathrm{a}}$ & $0.273^{\mathrm{b}}$ & $0.387^{\mathrm{b}}$ & $0.378^{\mathrm{b}}$ & 0.070 & 0.10 \\
\hline Serum fatty acids, $\mu \mathrm{Eq} / \mathrm{L}$ & $0.147^{\mathrm{a}}$ & $0.145^{\mathrm{a}}$ & $0.216^{\mathrm{b}}$ & $0.272^{\mathrm{c}}$ & 0.010 & $<0.01$ \\
\hline
\end{tabular}

${ }^{\mathrm{a}-\mathrm{c}}$ Within rows, means with different superscripts differ $(P<0.05)$.

${ }^{1}$ Blood samples were collected weekly (d 0-203), before the morning concentrate feeding during the experiment. Values obtained on d 0 were included as covariate within each respective analysis; therefore, values reported are covariately adjusted means.

${ }^{2} P$-value represents the concentrate energy source $\times$ Cr supplementation interaction.

${ }^{3}$ According to Mann et al. (2016).

$\mathrm{SEM}=3.2 ; 7.7$ and 9.0 for Cr-supplemented and nonsupplemented cows, respectively, SEM $=3.2$ ).

\section{DISCUSSION}

\section{Intake, BW, and BCS Variables}

The similar DMI, BCS, and BW traits among CSPO and CRN cows, as well as cows supplemented or not with Cr-propionate (Tables 2 and 3), corroborate that cows from all treatments similarly consumed excessive energy, which was designed to impair insulin sensitivity as in previous accomplished by our research group (Leiva et al., 2015, 2017b). Although estimated $\mathrm{NE}_{\mathrm{L}}$ intake was below the targeted $160 \%$ (Table 2), BW and BCS gain during the experimental period was equivalent to Leiva et al. (2015), and thus adequate to test our main hypotheses. Moreover, starch and crude fat intake, as a percentage of DMI, differed between CRN and CSPO cows, as designed (Table 2), although such differences were not sufficient to alter daily $(\mathrm{kg} / \mathrm{d})$ starch intake between concentrate energy treatments

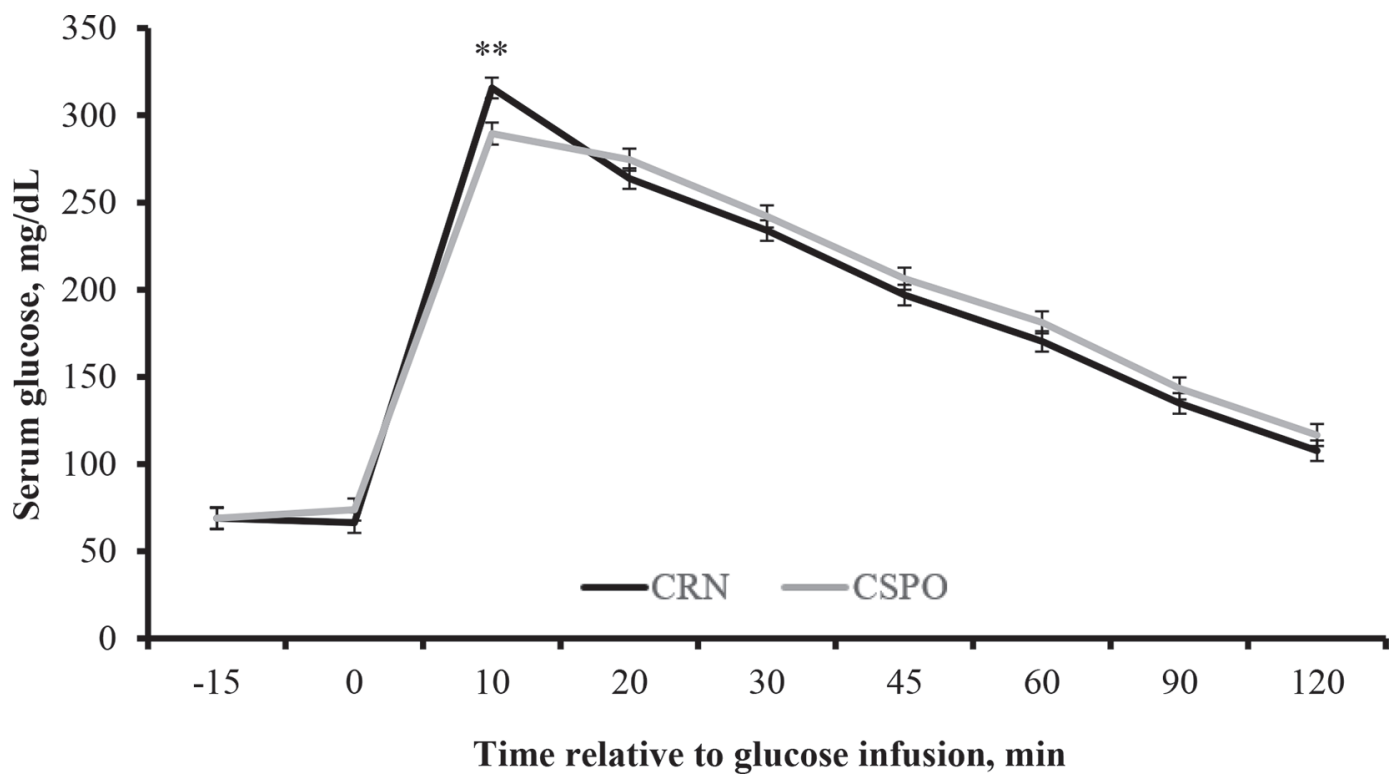

Figure 4. Serum glucose concentrations following a glucose tolerance test (intravenous infusion of $0.5 \mathrm{~g}$ of glucose $/ \mathrm{kg}$ of BW at $0 \mathrm{~min}$ ) of $3 / 4$ Holstein $\times 1 / 4$ Gir dairy cows consuming excessive energy during mid to late lactation and receiving in a $2 \times 2$ factorial arrangement design (1) concentrate based only on ground corn (CRN; $\mathrm{n}=20$ ) or including 8\% (DM basis) of Ca salts of palm oil (EnerFAT Kemin Agrifoods South America, Indaiatuba, São Paulo, Brazil; CSPO; n = 20), and (2) supplemented ( $\mathrm{n}=20)$ or not $(\mathrm{n}=20)$ with $2.5 \mathrm{~g} / \mathrm{d}$ of Cr-propionate (10 mg of Cr/cow daily; KemTrace 0.4\% Cr; Kemin Agrifoods South America). Values obtained on d 0 were included as covariate; therefore, values reported are covariately adjusted means. A concentrate type $\times$ min interaction was detected $(P<0.01)$. Within minutes, $* * P \leq 0.01$. Error bars represent SEM. 
(Table 2). This latter outcome can be associated with the starch content of the corn silage, which contributed to nearly $50 \%$ of the dietary DM and likely hindered major differences in starch intake between CRN and CSPO cows. Hence, concentrate energy source or $\mathrm{Cr}$ supplementation effects on all physiological and productive responses evaluated herein should not be associated with differences in energy intake among treatments (Vizcarra et al., 1998; Butler, 2003; Grummer, 1995), but with designed differences on Ca salts of palm oil and Cr-propionate intake.

\section{Serum Variables Evaluated Weekly and During the GTT}

Starch is the major dietary precursor for glucose in ruminants (Huntington, 1997) and is classified as an insulinogenic nutrient (Cabrita et al., 2007); hence, it would be expected that CRN cows had greater serum glucose and insulin concentration compared with CSPO cows (Garnsworthy et al., 2008). In turn, reduced hyperinsulinemia would lessen the incidence of insulin resistance in CSPO versus CRN cows (Moller and Flier, 1991). However, concentrate energy source effects on serum glucose, insulin, I:G, and HOMAIR during weekly sampling (Table 4) are suggestive of increased insulin sensitivity in CRN versus CSPO cows (Hayirli et al., 2001; Leiva et al., 2015, 2017b; Mann et al., 2016), which should be largely attributed to Cr-supplementation effects on CRN cows, as discussed in the next paragraph. Nevertheless, results from the GTT further suggest that CSPO cows experienced hyperinsulinemia and reduced insulin sensitivity, based on I:G and HOMA-IR results (Muniyappa et

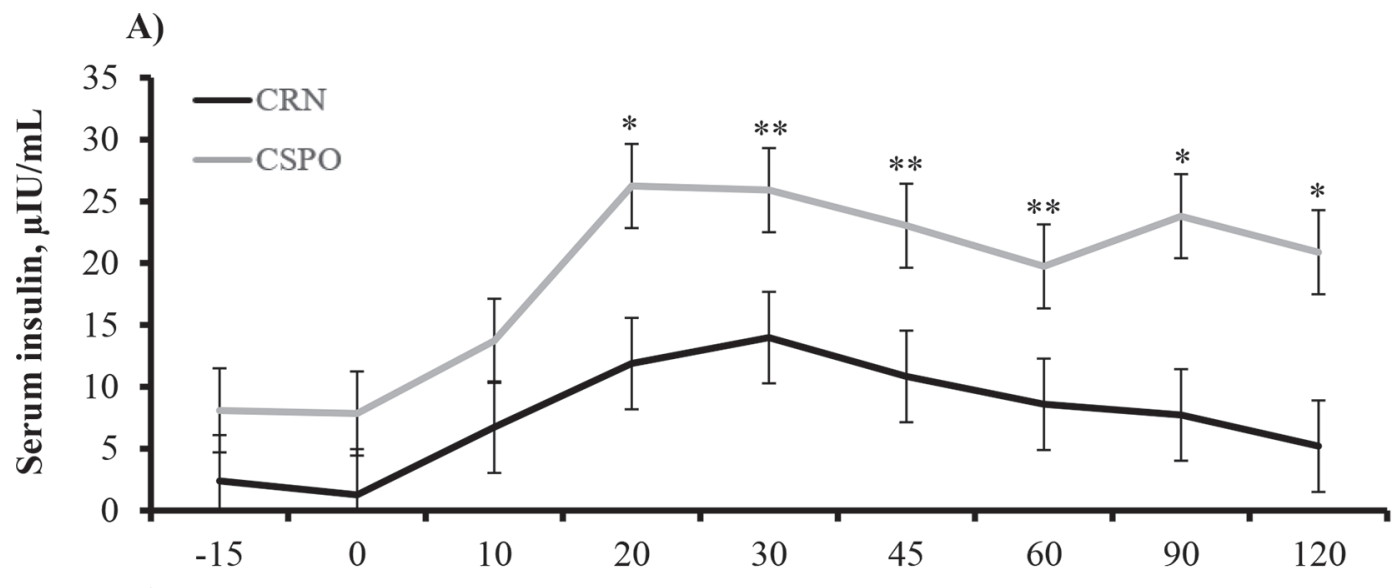

B)

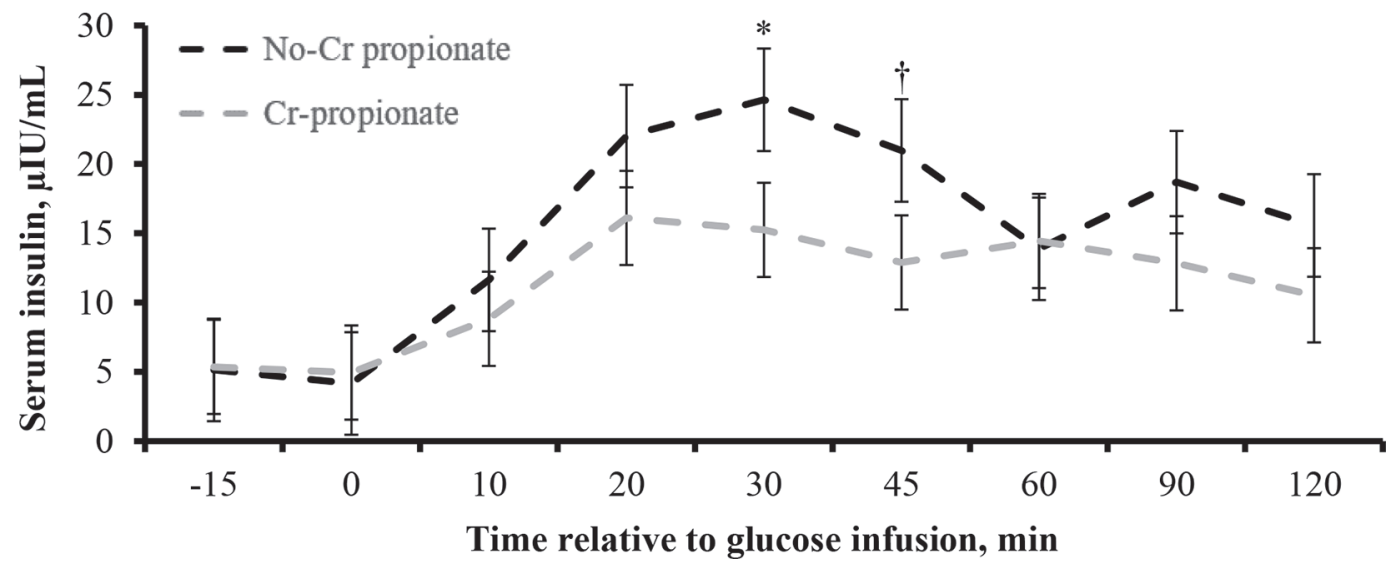

Figure 5. Serum insulin concentrations following a glucose tolerance test (intravenous infusion of $0.5 \mathrm{~g}$ of glucose/kg of BW at 0 min) of $3 / 4$ Holstein $\times 1 / 4$ Gir dairy cows consuming excessive energy during mid to late lactation and receiving in a $2 \times 2$ factorial arrangement design (1) concentrate based only on ground corn (CRN; $n=20$ ) or including 8\% (DM basis) of Ca salts of palm oil (EnerFAT Kemin Agrifoods South America, Indaiatuba, São Paulo, Brazil; CSPO; n = 20), and (2) supplemented ( $\mathrm{n}=20$ ) or not (n = 20) with 2.5 g/d of Cr-propionate (10 mg of $\mathrm{Cr} /$ cow daily; KemTrace $0.4 \% \mathrm{Cr}$; Kemin Agrifoods South America). Values obtained on d 0 were included as covariate; therefore, values reported are covariately adjusted means. Concentrate type $\times \min (\mathrm{A} ; P=0.02)$ and $\mathrm{Cr}$ supplementation $\times$ min $(\mathrm{B} ; P=0.03)$ interactions were detected. Within minute, ${ }^{*} * P \leq 0.01,{ }^{*} P \leq 0.05$, and $\dagger P \leq 0.10$. Error bars represent SEM. 
Table 6. Milk yield of $3 / 4$ Holstein $\times 1 / 4$ Gir dairy cows consuming excessive energy during mid to late lactation, and receiving in a $2 \times 2$ factorial arrangement design (1) concentrate based only on ground corn (CRN; $\mathrm{n}=20$ ) or including $8 \%$ (DM basis) of Ca salts of palm oil (CSPO; EnerFAT Kemin Agrifoods South America, Indaiatuba, São Paulo, Brazil; $\mathrm{n}=20)$, and (2) supplemented $(\mathrm{n}=20)$ or not $(\mathrm{n}=20)$ with $2.5 \mathrm{~g} / \mathrm{d}$ of Cr-propionate $(10 \mathrm{mg} \text { of } \mathrm{Cr} / \mathrm{cow} \text { daily; KemTrace } 0.4 \% \mathrm{Cr} \text {; Kemin Agrifoods South America })^{1}$

\begin{tabular}{|c|c|c|c|c|c|c|c|c|}
\hline Item & \multicolumn{4}{|c|}{ Concentrate type } & \multicolumn{4}{|c|}{ Cr supplementation } \\
\hline $3.5 \% \mathrm{FCM}, \mathrm{kg} / \mathrm{d}$ & 27.2 & 28.9 & 1.4 & 0.41 & 27.9 & 28.2 & 1.4 & 0.89 \\
\hline Milk protein, \% & 3.46 & 3.28 & 0.05 & 0.24 & 3.33 & 3.40 & 0.05 & 0.32 \\
\hline Milk TS, \% & 13.9 & 13.7 & 0.2 & 0.58 & 13.6 & 13.9 & 0.2 & 0.21 \\
\hline
\end{tabular}

${ }^{1}$ Milk production was recorded daily (d -15 to 203). Milk samples were collected weekly (d -15 to 203) from each cow, and analyzed for SCC via flow cytometry (AOAC, 1990) with a Somacount 300 instrument (Bentley Instruments Inc., Chaska, MN), and concentrations of fat, protein, and TS via infrared spectrometry (method 972.16; AOAC International, 1999), by a commercial laboratory (Clínica do Leite; Universidade de São Paulo, Piracicaba, Brazil). Daily milk yield was adjusted to FCM or TS-corrected milk (SCM) based on milk concentrations of fat and TS, respectively, of the concurrent week. Values obtained from d -15 to -1 were averaged and included as covariate within each respective analysis; therefore, values reported are covariately adjusted means.

A)

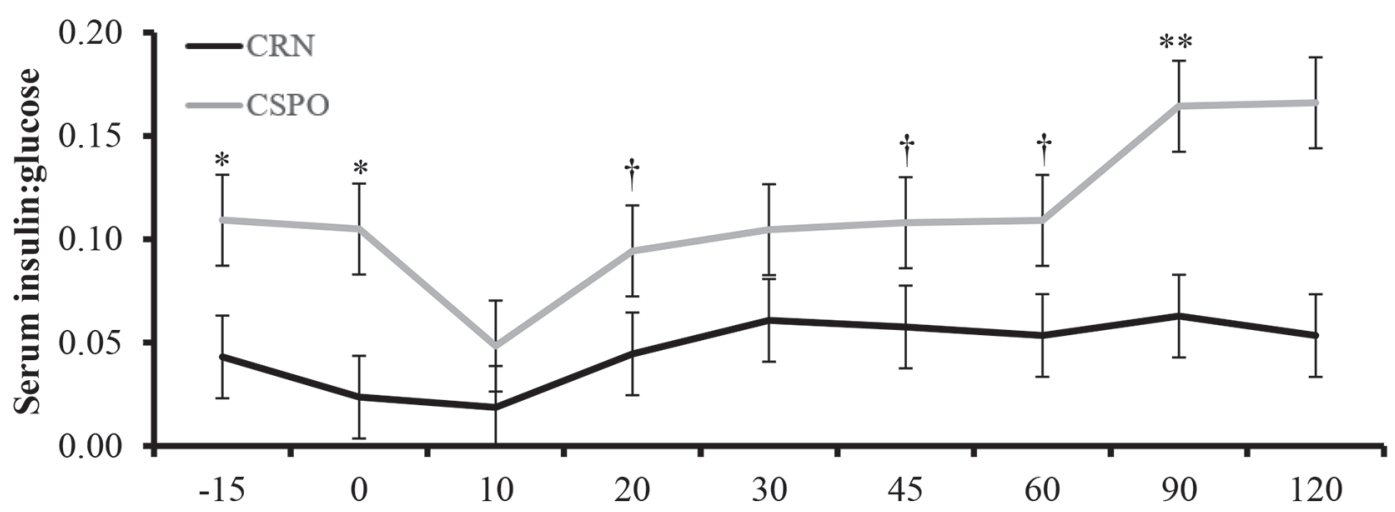

B)

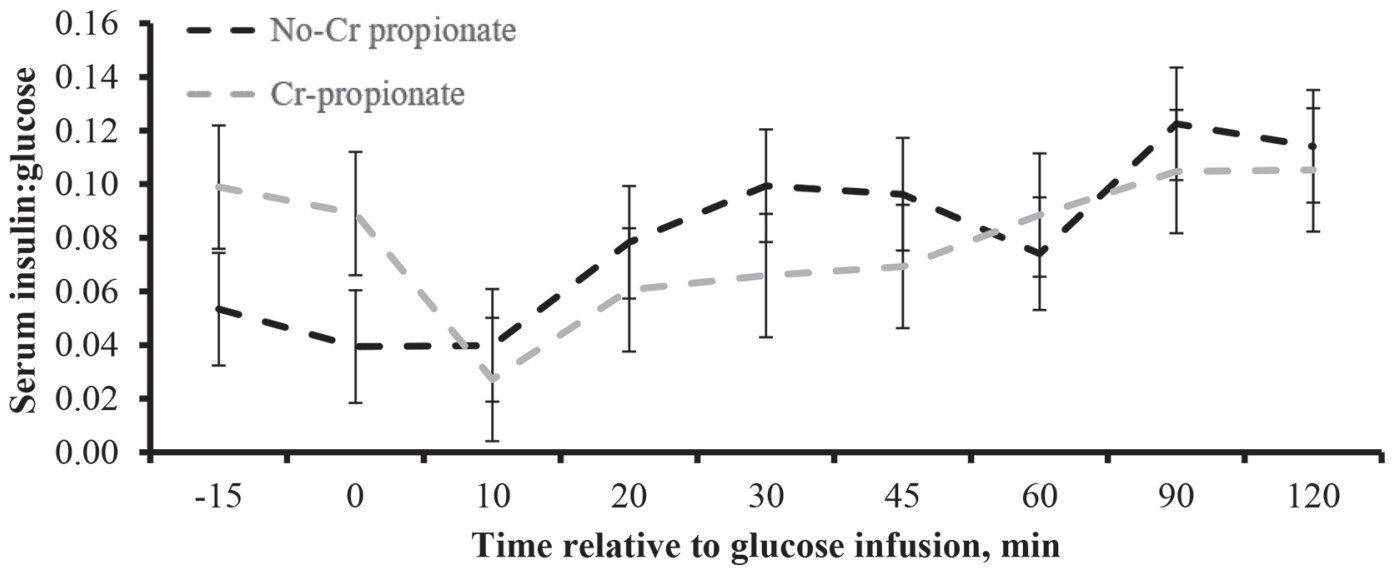

Figure 6. Serum insulin:glucose ratio following a glucose tolerance test (intravenous infusion of $0.5 \mathrm{~g}$ of glucose $/ \mathrm{kg}$ of $\mathrm{BW}$ at $0 \mathrm{~min}$ ) of $3 / 4$ Holstein $\times 1 / 4$ Gir dairy cows consuming excessive energy during mid to late lactation and receiving in a $2 \times 2$ factorial arrangement design (1) concentrate based only on ground corn $(\mathrm{CRN} ; \mathrm{n}=20$ ) or including $8 \%$ (DM basis) of Ca salts of palm oil (EnerFAT Kemin Agrifoods South America, Indaiatuba, São Paulo, Brazil; CSPO; $\mathrm{n}=20)$, and (2) supplemented ( $\mathrm{n}=20)$ or not ( $\mathrm{n}=20)$ with $2.5 \mathrm{~g} / \mathrm{d}$ of Cr-propionate (10 mg of $\mathrm{Cr} /$ cow daily; KemTrace $0.4 \% \mathrm{Cr}$; Kemin Agrifoods South America). Values obtained on d 0 were included as covariate; therefore, values reported are covariately adjusted means. Concentrate type $\times \min (\mathrm{A} ; P<0.01)$ and $\mathrm{Cr}$ supplementation $\times \min (\mathrm{B} ; P<0.01)$ interactions were detected. Within minute, ${ }^{* *} P \leq 0.01,{ }^{*} P \leq 0.05$, and $\dagger P \leq 0.10$. Error bars represent SEM. 
al., 2008; Bernhard et al., 2012), compared with CRN cows (Table 4; Figures 5 and 6). Perhaps differences in starch intake between CRN and CSPO cows were not sufficient to modulate hyperinsulinemia in CSPO cows. These outcomes should also be associated with greater serum fatty acid concentrations in CSPO versus CRN cows (Table 4). Inclusion of supplemental fat in diets to lactating dairy cows results in increased circulating fatty acid concentrations due to incomplete dietary lipid oxidation (Hayirli, 2006). In turn, fatty acid metabolism interferes with the intracellular insulin receptor-signaling cascade and reduces cell sensitivity to insulin (Lewis et al., 2002; Pires et al., 2007). Garnsworthy et al. (2008) also reported increased serum fatty acids when substituting wheat for Ca salts of palm oil, although plasma insulin concentrations decreased and plasma glucose concentrations did not change in fat-enriched diets. However, those authors formulated their experimental diets to meet $\mathrm{NE}_{\mathrm{L}}$ requirements of early-lactating cows. Cows from the present experiment were fed excessive energy during mid to late lactation, which is known to result in different fatty acid metabolism compared with that of early-lactating dairy cows (Bell, 1995). Moreover, insulin resistance increases mobilization of body fat reserves and subsequent fatty acid release into the circulation to compensate for the reduced uptake of glucose by body tissues (Barbour et al., 2002), which may have further contributed to concentrate energy source effects on serum fatty acid concentrations. Hence, replacing concentrate corn by Ca salts of palm oil failed to improve insulin sensitivity in dairy cows consuming excessive energy during mid to late lactation, likely due to their altered fatty acid metabolism (Bell, 1995) or insufficient decrease in daily starch intake.

Previous research reported that Cr-propionate supplementation to lactating and nonlactating Holstein $x$ Gir dairy cows affected serum concentrations of glucose, insulin, and fatty acids, and prevented the decrease in insulin sensitivity caused by excessive energy intake (Leiva et al., 2014, 2015). Chromium is a critical component of the glucose tolerance factor that facilitates the action of insulin on body cells (Mertz, 1992) via chromodulin - an oligopeptide that binds with high affinity to 4 chromic ions and enables $\mathrm{Cr}$ to be involved in the autoamplification of insulin signaling - maintaining the active conformation of insulin receptors and promoting greater glucose uptake (Vincent, 2001). Supplemental Cr-propionate may affect insulin-sensitivity traits in adipose and other body tissues through immunological signals such as proinflammatory cytokine response (Wellen and Hotamisligil, 2005). In our experiment, Cr-propionate reduced serum glucose concentrations independently of concentrate energy source in weekly samples, suggesting a potential increase in glucose uptake by body tissues across CSPO and CRN cows (Table 4). Conversely, Cr-propionate supplementation also reduced serum fatty acid concentrations in CSPO but not in CRN cows within weekly samples (Table 5), denoting enhanced dietary fat oxidation or increased body fat deposition due to increased glucose uptake in CSPO cows only (Barbour et al., 2002; Hayirli, 2006). Nonetheless, Cr-propionate supplementation reduced serum insulin, I:G, and HOMA-IR in CRN cows only within weekly samples (Table 5), which indicates that Cr supplementation improved basal insulin-sensitivity traits in CRN but not in CSPO cows (Muniyappa et al., 2008; Leiva et al., 2015, 2017b). Perhaps the elevated serum fatty acid concentrations in CSPO cows prevented the benefits of $\mathrm{Cr}$-propionate supplementation on insulin-sensitivity traits, such as enhanced insulin activity in target cells (Lewis et al., 2002; Pires et al., 2007). Conversely, Cr-propionate supplementation reduced hyperinsulinemia and I:G, although numerically, independently of concentrate energy source during the GTT (Figures 5 and 6). Hence, Cr-propionate supplementation was effective in improving insulin-sensitivity traits in both CRN and CSPO cows when cows were exposed to supraphysiological circulating glucose concentrations as previously reported (Hayirli et al., 2001; Leiva et al., 2015, 2017b).

\section{Milk Production}

Reduced insulin sensitivity may negatively affect milk yield and mammary synthesis of milk constituents in lactating dairy cattle (McGuire et al., 1995; LeBlanc, 2010). However, milk variables were not affected by concentrate energy source (Table 6) despite differences detected for insulin sensitivity between CSPO and CRN cows; perhaps the magnitude of such differences among CSPO and CRN cows were not sufficient to affect milk yield and constituents. Garnsworthy et al. $(2008,2009)$ also reported that reducing starch intake by substituting wheat for Ca salts of palm oil did not affect milk yield, although milk fat was increased in cows receiving Ca salts of palm oil in both studies. Likewise, Cr-propionate supplementation also failed to increase milk yield despite improved insulin-sensitivity traits during weekly sampling and GTT compared with nonsupplemented cows, corroborating previous research from our group evaluating mid- to late-lactating Holstein $\times$ Gir dairy cows consuming excessive energy (Leiva et al., 2015, 2017b). However, Cr-propionate supplementation reduced milk fat, although such difference was not sufficient to affect $3.5 \%$ FCM yield (Table 6). Greater milk fat concentration in nonsupplemented cows may be associated with their greater serum fatty 
acid concentrations compared with cows supplemented with Cr-propionate, given that preformed fatty acids are taken up by the mammary gland and directly used for milk fat synthesis (Bauman and Griinari, 2003). It is important, however, that diets in the present experiment were formulated to provide excessive $\mathrm{NE}_{\mathrm{L}}$ and cows were assigned to this experiment after peak lactation. Hence, such diets allowed cows from all treatment combinations to produce their maximum milk, which may have hindered potential effects of concentrate energy source or Cr supplementation treatments on milk production variables.

\section{Reproductive Variables}

Insulin resistance has been shown to impair oocyte fertility (Adamiak, 2005; Leiva et al., 2015), which can be attributed to reduced mRNA concentrations of IGF-I-binding proteins as well as insulin receptors within small follicles (Baruselli et al., 2016). The lack of treatment differences for reproductive variables herein indicate that both concentrate energy sources and Cr-propionate supplementation failed to affect oocyte production and fertility in Holstein $\times$ Gir dairy cows consuming excessive energy during mid to late lactation. As in milk production variables, differences in insulin-sensitivity traits among treatment combinations were not sufficient to affect reproductive variables, although others have reported reproductive benefits of organic $\mathrm{Cr}$ supplementation to dairy cows consuming corn-based concentrate (Bryan et al., 2004; Soltan, 2010). Therefore, research is still warranted to develop strategies that mitigate potential reproductive losses caused by excessive energy intake and subsequent increase in insulin resistance in lactating Holstein $x$ Gir dairy cattle (Leiva et al., 2015, 2017b).

\section{CONCLUSIONS}

Inclusion of Ca salts of palm oil failed to enhance insulin-sensitivity traits, whereas Cr-supplementation was effective in improving basal insulin sensitivity in cows not receiving Ca salts of palm oil. Nonetheless, milk yield and reproductive outcomes were not affected concentrate energy source or $\mathrm{Cr}$ supplementation. It should be noted, however, that milk yield capacity is considered moderate to low in Holstein $\times$ Gir cattle (Madalena et al., 1979); hence, the animals used herein might not fully represent the metabolic and physiological aspects of high-producing Holstein cows. Nonetheless, research is still warranted to develop nutritional strategies that mitigate insulin resistance and optimize performance and welfare in Holstein and Holstein $\times$ Gir cows, given the negative relationship among excessive energy intake, insulin-sensitivity traits, and productive responses in lactating cattle (LeBlanc, 2010; Baruselli et al., 2016).

\section{ACKNOWLEDGMENTS}

The Fundação de Amparo à Pesquisa do Estado de São Paulo (São Paulo, Brazil) provided financial support for this research and for T. Leiva (grants \# 2014/13291-6 and 2014/14512-6).

\section{REFERENCES}

Adamiak, S. J. 2005. Impact of nutrition on oocyte quality: cumulative effects of nody composition and diet leading to hyperinsulinemia in cattle. Biol. Reprod. 73:918-926.

AOAC. 1990. Official Method of Analysis. 15th ed. Assoc. Off. Anal. Chem., Arlington, VA.

AOAC International. 1999. Official Method of Analysis. 16th ed. AOAC International, Arlington, VA.

Barbour, L. A., J. Shao, L. Qiao, L. K. Pulawa, D. R. Jensen, A. Bartke, M. Garrity, B. Draznin, and J. E. Friedman. 2002. Human placental growth hormone causes severe insulin resistance in transgenic mice. Am. J. Obstet. Gynecol. 186:512-517.

Baruselli, P. S., L. M. Vieira, M. F. Sá Filho, R. D. Mingoti, R. M. Ferreira, M. R. Chiaratti, L. H. Oliveira, J. N. Sales, and R. Sartori. 2016. Associations of insulin resistance later in lactation on fertility of dairy cows. Theriogenology 86:263-269.

Bauman, D. E., and J. M. Griinari. 2003. Nutritional regulation of milk fat synthesis. Annu. Rev. Nutr. 23:203-227.

Bell, A. W. 1995. Regulation of organic nutrient metabolism during transition from late pregnancy to early lactation. J. Anim. Sci. 73:2804-2819.

Bernhard, B. C., N. C. Burdick, R. J. Rathmann, J. A. Carroll, D. N. Finck, M. A. Jennings, T. R. Young, and B. J. Johnson. 2012. Chromium supplementation alters both glucose and lipid metabolism in feedlot cattle during the receiving period. J. Anim. Sci. 90:4857-4865.

Bilby, T. R., J. Block, B. C. do Amaral, O. Sa Filho, F. T. Silvestre, P. J. Hansen, C. R. Staples, and W. W. Thatcher. 2006. Effects of dietary unsaturated fatty acids on oocyte quality and follicular development in lactating dairy cows in summer. J. Dairy Sci. 89:3891-3903.

Bryan, M. A., M. T. Socha, and D. J. Tomlinson. 2004. Supplementing intensively grazed late-gestation and early-lactation dairy cattle with chromium. J. Dairy Sci. 87:4269-4277.

Butler, W. R. 2003. Energy balance relationships with follicular development ovulation and fertility in postpartum dairy cows. Livest. Prod. Sci. 83:211-218.

Cabrita, A. R. J., R. J. B. Bessa, S. P. Alves, R. J. Dewhurst, and A. J. M. Fonseca. 2007. Effects of dietary protein and starch on intake, milk production, and milk fatty acid profiles of dairy cows fed corn silage-based diets. J. Dairy Sci. 90:1429-1439.

Curley, K. O., Jr., D. A. Neuendorff, A. W. Lewis, J. J. Cleere, T. H. Welsh Jr., and R. D. Randel. 2008. Functional characteristics of the bovine hypothalamic-pituitary-adrenal axis vary with temperament. Horm. Behav. 53:20-27.

Garnsworthy, P. C., A. A. Fouladi-Nashta, G. E. Mann, K. D. Sinclair, and R. Webb. 2009. Effect of dietary-induced changes in plasma insulin concentrations during the early post partum period on pregnancy rate in dairy cows. Reproduction 137:759-768.

Garnsworthy, P. C., A. Lock, G. E. Mann, K. D. Sinclair, and R. Webb. 2008. Nutrition, metabolism, and fertility in dairy cows: 1 . Dietary energy source and ovarian function. J. Dairy Sci. 91:3814-3823.

Grummer, R. R. 1995. Impact of changes in organic nutrient metabolism on feeding the transition dairy cow. J. Anim. Sci. 73:28202833. 
Hayirli, A. 2006. The role of exogenous insulin in the complex of hepatic lipidosis and ketosis associated with insulin resistance phenomenon in postpartum dairy cattle. Vet. Res. Commun. 30:749-774.

Hayirli, A., D. R. Bremmer, S. J. Bertics, M. T. Socha, and R. R. Grummer. 2001. Effect of chromium supplementation on production and metabolic parameters in periparturient dairy cows. J. Dairy Sci. 84:1218-1230.

Huntington, G. B. 1997. Starch utilization by ruminants: From basics to the bunk. J. Anim. Sci. 75:852-867.

LeBlanc, S. 2010. Monitoring metabolic health of dairy cattle in the transition period. J. Reprod. Dev. 56:S29-S35.

Leiva, T., R. F. Cooke, A. C. Aboin, F. L. Drago, R. Gennari, and J. L. M. Vasconcelos. 2014. Effects of excessive energy intake and supplementation with chromium propionate on insulin resistance parameters in non-lactating dairy cows. J. Anim. Sci. 92:775-782.

Leiva, T., R. F. Cooke, A. P. Brandão, A. C. Aboin, J. Ranches, and J. L. M. Vasconcelos. 2015. Effects of excessive energy intake and supplementation with chromium propionate on insulin resistance parameters in lactating dairy cows. Livest. Sci. 180:121-128.

Leiva, T., R. F. Cooke, A. P. Brandão, K. M. Schubach, L. F. D. Batista, M. F. Miranda, E. A. Colombo, R. O. Rodrigues, J. R. G. Junior, R. L. A. Cerri, and J. L. M. Vasconcelos. 2017a. Supplementing an immunomodulatory feed ingredient to modulate thermoregulation, physiological, and production responses in lactating dairy cows under heat stress conditions. J. Dairy Sci. 100:4829 4838. https://doi.org/10.3168/jds.2016-12258.

Leiva, T., and R. F. Cooke., A. PBrandão, U., R. O. Pardelli, F. N. Rodrigues, Corrá, and J. L. M. Vasconcelos. 2017b. Effects of concentrate type and chromium propionate supplementation on insulin sensitivity parameters, milk production, and reproductive outcomes of lactating dairy cows consuming excessive energy. Animal 11:436-444.

Lewis, G. F., A. Carpentier, K. Adehi, and A. Giaccca. 2002. Disordered fat storage and mobilization in the pathogenesis of insulin resistance and type 2 diabetes. Endocr. Rev. 23:201-229.

Madalena, F. E., M. L. Martinez, and A. F. Freitas. 1979. Lactation curves of Holstein-Friesian and Holstein-Friesian $\times$ Gir cows. Anim. Prod. 29:101-107.

Mann, S., F. L. Yepes, M. Duplessis, J. J. Wakshlag, T. R. Overton, B. P. Cummings, and D. V. Nydam. 2016. Dry period plane of energy: Effects on glucose tolerance in transition dairy cows. J. Dairy Sci. 99:701-717.

McGuire, M. A., J. M. Griinari, D. A. Dwyer, and D. E. Bauman. 1995. Role of insulin in the regulation of mammary synthesis of fat and protein. J. Dairy Sci. 78:816-824.
Mertz, W. 1992. Chromium. History and nutritional importance. Biol. Trace Elem. Res. 32:3-8.

Moller, D. E., and J. S. Flier. 1991. Insulin resistance-Mechanisms, syndromes, and implications. N. Engl. J. Med. 325:938-948.

Muniyappa, R., S. Lee, H. Chen, and M. J. Quon. 2008. Current approaches for assessing insulin sensitivity and resistance in vivo: Advantages, limitations, and appropriate usage. Am. J. Physiol. Endocrinol. Metab. 294:E15-E26.

NRC. 2001. Nutrient Requirements of Dairy Cattle. 7th rev. ed. Natl. Acad. Sci., Washington, DC.

Overholt, M. F., E. K. Arkfeld, K. B. Wilson, D. A. Mohrhauser, D. A. King, T. L. Wheeler, A. C. Dilger, S. D. Shackelford, and D. D. Boler. 2016. Effects of marketing group and production focus on quality and variability of adipose tissue and bellies sourced from a commercial processing facility. J. Anim. Sci. 94:5168-5176.

Pires, J. A. A., A. H. Souza, and R. R. Grummer. 2007. Induction of hyperlipidemia by intravenous infusion of tallow emulsion causes insulin resistance in Holstein cows. J. Dairy Sci. 90:2735-2744.

Shiang, K. D. 2004. The SAS calculations of areas under the curve (AUC) for multiple metabolic readings. Accessed Mar. 15, 2016. http://www.lexjansen.com/wuss/2004/posters/c_post_the_sas_ calculations_.pdf.

Soltan, M. A. 2010. Effect of dietary chromium supplementation on productive and reproductive performance of early lactating dairy cows under heat stress. J. Anim. Physiol. Anim. Nutr. (Berl.) 94:264-272.

Van Saun, R. J., and C. J. Sniffen. 1996. Nutritional management of the pregnant dairy cow to optimize health, lactation and reproductive performance. Anim. Feed. Tech. Sci. 59:13-26.

Vincent, J. B. 2001. The bio-inorganic chemistry of chromium (III). Polyhedron 20:1-26.

Vizcarra, J. A., R. P. Wettemann, J. C. Spitzer, and D. G. Morrison. 1998. Body condition at parturition and postpartum weight gain influence luteal activity and concentrations of glucose, insulin, and nonesterified fatty acids in plasma of primiparous beef cows. J. Anim. Sci. 76:927-936.

Wellen, K. E., and G. S. Hotamisligil. 2005. Inflammation, stress, and diabetes. J. Clin. Invest. 115:1111-1119.

Wildman, E. E., G. M. Jones, P. E. Wagner, R. L. Boman, H. F. Troutt, and T. N. Lesch. 1982. A dairy cow body condition scoring system and its relationship to selected production characteristics. J. Dairy Sci. 65:495-501. 